\title{
Occurrence of Pathotypes of Escherichia coli in Aquatic Environment
}

\author{
B. Koteswar ${ }^{1 *}$, A. Devivaraprasad $\operatorname{Reddy}^{2}$, G. Ravi $^{3}$, and Indrani Karunasagar ${ }^{2}$ \\ ${ }^{1}$ National Institute of Fisheries Post Harvest Technology and Training, \\ Vishakhapatnam, Andhra Pradesh, India \\ ${ }^{2}$ Department of Fisheries Microbiology, College of Fisheries, Mangalore, Karnataka, India \\ ${ }^{3}$ Fisheries Research Station, PVNR Telangana Veterinary University, Palair - 507 157, India \\ *Corresponding author
}

\begin{abstract}
Keywords
Pathotypes of $E$. coli, Incidence,

Pond water,

Seafood, Sediment.

Article Info

Accepted:

10 August 2017

Available Online:

10 September 2017 The pathogenic E. coli strains can cause a variety of diseases, including diarrhoea, dysentery, and haemolytic uremic syndrome, bladder and kidney infections. Different strains are usually associated with different diseases; this versatility of $E$. coli strains is due to the different strains possessing unique virulence genes. Though E. coli contamination of tropical seafood is quite common, the distribution of different pathogenic types in seafood is not studied in detail except for Shiga toxin producing E. coli. The objective of this study was identification of the pathotypes, if any, associated with them. E. coli was isolated from several fresh and frozen finfish samples, molluscs, cephalopods and crustacean shellfishes, and water and sediment samples. Among the different aquatic environment and seafood samples examined, only two squids and one flat fish sample was found positive for the presence of the virulence gene, eaeA. These three samples yielded atypical EPEC (eaeAt, $b f p-$, st $x$-), while being negative for other virulence genes by PCR. Other samples though positive for $E$. coli, did not possess the virulence genes. The results highlight the presence of some of the pathotypes of $E$. coli in seafood samples and hence are recognized as a potential threat to human health.
\end{abstract}

\section{A B S T R A C T}

Escherichia coli are recognized indicators of faecal contamination. However, this perspective has changed with the ability of some strains of $E$. coli to cause human illness.

\section{Introduction}

The genus Escherichia is a member of the Enterobacteriaceae family and E. coli is the most common aerobic organism in the intestinal tract of man and warm-blooded animals. Most of the E. coli strains are harmless commensals that colonize the gastrointestinal tract and probably play important roles in maintaining intestinal physiology. E. coli plays a crucial role in food digestion by producing vitamin $\mathrm{K}$ from undigested material in the large intestine.
An important member of the normal intestinal micro biota of humans and other mammals, $E$. coli has also been widely exploited as a cloning host in recombinant DNA technology (Kaper et al., 2004). However, some strains of E. coli are pathogenic and can cause diarrheal disease. E. coli strains are differentiated based on a serotyping scheme involving $\mathrm{O}$ (somatic), $\mathrm{H}$ (flagellar) and $\mathrm{K}$ (capsular) antigens. Pathogenic E. coli is divided into specific groups depending on virulence, 
clinical symptoms and distinct $\mathrm{O}: \mathrm{H}$ antigens. The important groups are: enteropathogenic E. coli (EPEC), enterotoxigenic E. coli (ETEC), enteroinvasive E. coli (EIEC), diffuse-adhering $E$. coli (DAEC), enteroaggregative $E$. coli (EAggEC) and entero hemorrhagic E. coli (EHEC), or Shiga toxin producing $E$. coli (STEC) (Donnenberg., 2005). Several E. coli pathotypes have been implicated in diarrheal illness, a major public health problem worldwide, with over two million deaths occurring each year (Kosek et al., 2003). Besides being the major cause of human urinary tract infections, $E$. coli has been linked to cause many other diseases like pneumonia, meningitis and traveller's diarrhea. Pathogenic strains of E. coli can cause severe diarrhea in all age groups by producing a powerful endotoxin. Treating $E$. coli infections with antibiotics may actually place the patient in severe shock that could possibly lead to the death. The main source of E. coli infections have been faecal contaminated water and contaminated food handlers. Outbreaks by pathogenic E. coli have mostly involved undercooked ground beef and raw milk, however, poor hygiene, cross contamination by food handlers or dirty water may transfer the organism. Also, such strains may accumulate in filter feeding bivalves cultured in contaminated waters. Though the E. coli is not indigenous to the aquatic environment, it may survive and even multiply in warm tropical waters (Rhodes and Kator, 1988; Jimenez et al., 1989) and thus also isolated from presumed unpolluted waters.

\section{Materials and Methods}

\section{Sample collection}

Various aquatic samples which included twenty two finfish, thirty shellfish, six water and three sediment samples were collected in sterile polythene bags from fish landing centre and fish ponds in Mangalore. Sewage water was collected from sewage treatment plant. Sediment samples were collected from fish ponds and also from a region in Mangalore where sewage water is discharged into the sea. Water samples from sea and freshwater ponds were collected in sterile polythene bags and brought to the laboratory for further analysis

\section{Enrichment}

$25 \mathrm{~g}$ of each sample (finfish, shellfish, frozen fish,) was taken and homogenized with 225 $\mathrm{ml}$ of physiological saline in a homogenizer for $5 \mathrm{~min} .1 \mathrm{ml}$ each of homogenized samples was then inoculated into two tubes containing $9 \mathrm{ml}$ each of $E$. coli broth. One tube was incubated at $37^{\circ} \mathrm{C}$ and the other at $44.5^{\circ} \mathrm{C}$ for $24 \mathrm{hr}$ in a water bath. The same procedure was repeated with sediment sample.

A suspension was prepared by mixing $25 \mathrm{~g}$ sediment with $225 \mathrm{ml}$ of physiological saline and then inoculated as above. In the case of water and ice (melted), $1 \mathrm{ml}$ of the sample was directly inoculated to two tubes containing $9 \mathrm{ml}$ of E.C broth. As detailed above, one tube was incubated at $37{ }^{\circ} \mathrm{C}$ and the other at $44.5^{\circ} \mathrm{C}$ for $24 \mathrm{hr}$.

\section{Selective plating}

One loopful of culture from the enrichment broth was streaked onto three selective agar plates i.e. Sorbitol- MacConkey agar, MacConkey and EMB agar plates. The plates were incubated at $37^{\circ} \mathrm{C}$ for $24 \mathrm{hr}$. Colourless colonies, reddish colonies and colonies showing metallic sheen that developed on Sorbitol- MacConkey agar, MacConkey agar and Eosine methylene blue agar respectively, were picked and subjected to further biochemical tests for the identification of $E$. coli 


\section{Biochemical tests}

Biochemical tests like gram's straining, indole test, Methyl Red-Voges Proskauer test (MR-VP) and Simmon's citrate test were done for the identification and confirmation of E. coli. Using molecular methods for identifying pathotypes of $E$. coli.

\section{PCR for confirmation of $E$. coli pathotypes}

\section{Extraction of DNA}

Test cultures were grown overnight in $3 \mathrm{ml}$ Luria Bertani broth. $50 \mu \mathrm{l}$ aliquot of this culture was suspended in $450 \mu \mathrm{l}$ of $1 \mathrm{x}$ TE buffer $\left(\mathrm{pH} \mathrm{8.0)}\right.$ and lysed at $98^{\circ} \mathrm{C}$ for $15 \mathrm{~min}$ in hot bath, followed by snap cooling on ice. The cell debris was settled by centrifugation at $10,000 \mathrm{rpm}$ for $5 \mathrm{~min}$ and the supernatant was used for PCR amplification. All the PCR reactions were performed in PTC 200 thermal cycler (M.J. Research Inc., USA).

\section{PCR amplification}

PCR reaction was carried out in $30 \mu \mathrm{l}$ reaction mixture containing10X buffer $(100 \mathrm{mM}$ Tris$\mathrm{HCl}, \mathrm{pH} 8.3,20 \mathrm{mM} \mathrm{MgCl} 2,500 \mathrm{mM} \mathrm{KCl}$, and $0.1 \%$ gelatin), $200 \mathrm{mM}$ of dNTPs (dATP, dTTP, dGTP, dCTP), 10 pmol each of forward and reverse primers and 1.0 unit of Taq DNA polymerase. The buffer for Taq DNA polymerase, dNTPs and Taq polymerase was obtained from Bangalore Genie, Bangalore. In a sterile PCR tube $22.1 \mu \mathrm{l}$ of sterile distilled water, $3 \mu \mathrm{l}$ of $10 \mathrm{X}$ assay buffer, $0.6 \mu 1$ of $200 \mathrm{mM}$ dNTP mix, $2 \mu \mathrm{l}$ of each primer (forward and reverse) (10 $\mathrm{pmol} / \mathrm{ml}), 0.3 \mu \mathrm{l}$ of Taq polymerase and $2 \mu \mathrm{l}$ of template DNA solution was taken. Amplification was carried out in a thermocycler, (MJ-Research, USA) and programmed for required number of cycles of amplification. Each cycle consisted of denaturation, annealing, and extension. The programme included an initial denaturation at $94{ }^{\circ} \mathrm{C}$ for $5 \mathrm{~min}$, and a final delay at $72{ }^{\circ} \mathrm{C}$ for 5-10 min. The gene cycling condition for the above mentioned genes of the various pathotypes of $E$. coli is given in table 1 .

\section{Detection of amplified DNA}

PCR amplified product were resolved by electrophoresis in a $1.5 \%$ agarose gel to visualize the amplicons. The agarose gels were prepared in $1 \mathrm{X}$ TAE buffer. When the molten agarose had cooled to below $65^{\circ} \mathrm{C}$, ethidium bromide was added to a final concentration of $0.5 \mu \mathrm{g} / \mathrm{ml}$ and the gel was cast. $20 \mu \mathrm{l}$ of the amplicon was mixed with 4 $\mu \mathrm{l}$ of $6 \mathrm{X}$ loading buffer and loaded into the wells. 100 bp ladder (Bangalore Genei, Bangalore) was used as a molecular weight marker. Electrophoresis was carried out at 80120 volts and the bands were visualized under UV light. The gels were photographed using the GelDoc documentation system (Herolab, Weisloch, Germany).

\section{Results and Discussion}

A total of sixty-six samples comprising of fish, shrimps, clams, mussels and squids collected from fish landing centre and markets in Mangalore were analyzed. Water and sediment samples were collected from fish ponds in the campus of College of Fisheries, Mulky estuary and seawater was from Mangalore coast. Sewage samples were collected from a sewage treatment plant in Yekkur, Mangalore. All samples were analyzed for the presence of pathotypes of $E$. coli. Finfish samples comprising sardines, mackerels, eel, flat fish, anchovies and croaker were analyzed. Among these finfish samples, E. coli was isolated from all varieties except eel wherein only one sample was analyzed. Out of 22 finfish samples studied, E. coli was observed in 18 samples. The shellfish samples comprised clams, mussels, 
shrimps, squid and oysters. 27 out of 30 shellfish samples were positive for E. coli. Six water samples were analyzed (3 from fishpond, 2 seawater samples, and 1 from sewage outfall near the fish pond on the campus). All the water samples were positive for $E$. coli. All the three sediment samples analyzed for the presence of $E$. coli were positive. Three frozen fish (mackerels) samples were analyzed for the presence of $E$. coli and only one was positive for E. coli. Two ice samples from landing centre were analyzed for the presence of E. coli and both were positive.

\section{Detection of pathotypes of $E$. coli by PCR}

Aquatic environmental samples and the isolates obtained from them were subjected to PCR to detect the presence of stx 2 gene of EHEC, eaeA gene of EHEC and EPEC, lt and st gene of ETEC, ipaH gene of EIEC, daaE gene of DAEC, aafII gene of EAEC. Three (one flat fish and two squid samples) of 66 samples were positive for eaeA (common for EHEC and EPEC). The gel picture showing amplification of $384 \mathrm{bp}$ fragment of eaeA gene in three isolates is presented in figure 1. The percentage of this genotype was $4.54 \%$. None of the samples and their respective isolates was positive for other pathotypes of E. coli genes by PCR.

Traditionally, E. coli has been used as an indicator organism for the presence of other pathogenic bacteria in water and food. More than 200 serotypes of E. coli are categorized under at least six pathogenic typesenteropathogenic $E$. coli (EPEC), enterotoxigenic $E$. coli (ETEC), enterohaemorrhagic E. coli or Shiga toxinproducing E. coli (EHEC or STEC), enteroinvasive $E$. coli (EIEC) and enteroadherent/ aggregative $E$. coli (EAEC/EaggEC), diffusely adherent E. coli (Donnenberg., 2005). Some E. coli strains can cause a variety of diseases, including diarrhea, dysentery, hemolytic uremic syndrome and bladder and kidney infections. Infections due to Shiga toxin- producing $E$. coli (STEC) can result in severe bloody diarrhea (hemorrhagic colitis) and lifethreatening complications such as hemolytic uremic syndrome (HUS) (Fischer et al., 2001). Different strains are usually associated with different diseases. This versatility of $E$. coli strains is due to different strains having acquired different sets of virulence genes (Teophilo et al., 2002). Though E. coli contamination of tropical seafood is quite common, the distribution of different types in seafood is less studied except for Shiga toxinproducing E. coli (Karunasagar et al., 2005). Incubation temperature has a profound effect on growth of some pathotypes of E. coli. Though $44.5^{\circ} \mathrm{C}$ is the selective temperature for growth of faecal coliforms and E. coli, circumstantial evidence suggests that some strains of pathogenic E. coli like EHEC O157: $\mathrm{H} 7$ are unable to grow at $44.5^{\circ} \mathrm{C}$ (Varnam and Evans, 1991). Tusharamani (2001) showed that for the isolation of $E$. coli, incubation of broth at $44.5^{\circ} \mathrm{C}$ would be important. The incidence of $E$. coli was higher at $44.5^{\circ} \mathrm{C}$ compared to $37^{\circ} \mathrm{C}$. This could be due to the overgrowth of E. coli by other coliforms at $37^{\circ} \mathrm{C}$. The results of this study showed that incidence of E. coli was higher at $37{ }^{\circ} \mathrm{C}$ compared to $44.5^{\circ} \mathrm{C}$. The incubation temperature of $44.5^{\circ} \mathrm{C}$ would be selective for E. coli.

In the present study showed the maximum occurrence of E. coli in seafood samples analyzed. Kumar et al., (2001) reported 78\% incidence of $E$. coli in fish and $70 \%$ in clam and $100 \%$ in oyster. Among 66 samples analyzed, 57 were presumptively identified as positive for $E$. coli by conventional methods. In this study, the incidence of $E$. coli was 86.6 $\%$, which can be comparable with results obtained by Kumar et al., (2001). 
Primer sequences used for detection of enterohaemorrhagic $\boldsymbol{E}$. coli

\begin{tabular}{|c|c|c|c|}
\hline Gene & Primer sequence $\left(5^{\prime}-3^{\prime}\right)$ & Size of the product (bp) & References \\
\hline $\begin{array}{l}\text { stx } 1 \text { and } \\
\text { stx2 }\end{array}$ & $\begin{array}{l}\text { GAACGAAATAATTTATATGT } \\
\text { TACTGACATTGTTAGTTT }\end{array}$ & 900 & Lin et al., 1993 \\
\hline stx 2 & $\begin{array}{l}\text { CCATGACAACGGACAGCAGTT } \\
\text { CCTGTCAACTGAGCAGCACTTTG }\end{array}$ & 779 & $\begin{array}{l}\text { Fagan et al., } \\
1999\end{array}$ \\
\hline eae $A$ & $\begin{array}{l}\text { GACCCGGCACAAGCATAAGC } \\
\text { CCACCTGCAGCAACAAGAGG }\end{array}$ & 384 & $\begin{array}{l}\text { Paton and } \\
\text { Paton, } 1998\end{array}$ \\
\hline $\begin{array}{l}\text { stx } \\
\text { common }\end{array}$ & $\begin{array}{l}\text { GAGCGAAATAATTTATATGTG } \\
\text { TGATGATGGCAATTCAGTAT }\end{array}$ & 518 & $\begin{array}{l}\text { Yamasaki et } \\
\text { al., } 1996\end{array}$ \\
\hline
\end{tabular}

Primer sequences used to detect enterotoxigenic $E$. coli

\begin{tabular}{|c|l|c|c|}
\hline Gene & Primer sequence $\left(5^{\prime}-3^{\prime}\right)$ & Size of the product $(\mathrm{bp})$ & References \\
\hline$L t$ & $\begin{array}{l}\text { GGCGACAGATTATACCGTGC } \\
\text { CCGAAATTCTGTTATATATGTC }\end{array}$ & 696 & Schultz, 1994 \\
\hline$S t$ & $\begin{array}{l}\text { TTAATAGCACCCGGTACAAGCACG } \\
\text { CTTGACTTCAAAAGAGAAAATTAC }\end{array}$ & 147 & $\begin{array}{c}\text { Olsvik and } \\
\text { Strockbine, }\end{array}$ \\
\hline
\end{tabular}

Primers sequences used for detection of enteropathogenic $E$. coli

\begin{tabular}{|c|l|c|l|}
\hline Gene & Primer sequence $\left(5^{\prime}-3^{\prime}\right)$ & Size of the product (bp) & References \\
\hline$b f p$ & $\begin{array}{l}\text { AAT GGT GCT TGC GCT TGC GC } \\
\text { GCC GCT TTA TCC AAC TGGTA }\end{array}$ & 324 & $\begin{array}{l}\text { Gunzberg } e t \\
\text { al., } 1995\end{array}$ \\
\hline$e a e A$ & $\begin{array}{l}\text { GACCCGGCACAAGCATAAGC } \\
\text { CCACCTGCAGCAACAAGAGG }\end{array}$ & 384 & $\begin{array}{l}\text { Paton and } \\
\text { Paton, } 1998\end{array}$ \\
\hline
\end{tabular}

Primer sequence used for detection of enteroinvasive $E$. coli

\begin{tabular}{|l|c|c|c|}
\hline Gene & Primer sequence $\left(5^{\prime}-3^{\prime}\right)$ & Size of the product $(\mathrm{bp})$ & \multicolumn{1}{|c|}{ References } \\
\hline ipaH & CTC GGC ACG TTT TAA TAG TCTGG & 933 & Vidal et al., \\
& GTG GAG AGC TGA AGT TTC TCTGC & & 2004 \\
\hline
\end{tabular}

Primers sequence used for detection of enteroadherent- aggregative $E$. coli

\begin{tabular}{|l|l|c|l|}
\hline Gene & Primer sequence $\left(5^{\prime}-3^{\prime}\right)$ & Size of the product $(\mathrm{bp})$ & References \\
\hline aafII & CAC AGG CAA CTG AAA TAA GTC TGG & 378 & Vidal et al., \\
& ATT CCC ATG ATG TCA AGC ACT TC & & 2004 \\
\hline
\end{tabular}

Primers sequence used for detection of diffusely adherent $E$. coli

\begin{tabular}{|c|l|c|l|}
\hline Gene & Primer sequence $\left(5^{\prime}-3^{\prime}\right)$ & Size of the product (bp) & References \\
\hline daaE & GAA CGT TGG TTA ATG TGG GGT AA & 542 & $\begin{array}{l}\text { Vidal } \text { et al., } \\
\\
\text { TAT TCA CCG GTC GGT TAT CAG T }\end{array}$ \\
\hline
\end{tabular}


Table.1 Cycling conditions for amplification of different genes of E. coli

\begin{tabular}{|l|l|l|l|l|c|}
\hline Pathotype & \multicolumn{1}{|c|}{ Gene } & Denaturation & Annealing & Extension & No. of cycles \\
\hline \multirow{2}{*}{ EHEC } & stxland stx 2 & $94^{\circ} \mathrm{C}-1 \mathrm{~min}$ & $58^{\circ} \mathrm{C}-90 \mathrm{sec}$ & $72^{\circ} \mathrm{C}-90 \mathrm{sec}$ & 35 \\
\cline { 2 - 6 } & stx2 & $95^{\circ} \mathrm{C}-30 \mathrm{sec}$ & $58^{\circ} \mathrm{C}-40 \mathrm{sec}$ & $72^{\circ} \mathrm{C}-90 \mathrm{sec}$ & 35 \\
\cline { 2 - 6 } & Stx common & $94^{\circ} \mathrm{C}-1 \mathrm{~min}$ & $58^{\circ} \mathrm{C}-90 \mathrm{sec}$ & $72^{\circ} \mathrm{C}-90 \mathrm{sec}$ & 36 \\
\hline \multirow{2}{*}{ EPEC\& } & $\begin{array}{l}\text { eae A } \\
\text { common }\end{array}$ & $95^{\circ} \mathrm{C}-30 \mathrm{sec}$ & $58^{\circ} \mathrm{C}-40 \mathrm{sec}$ & $72^{\circ} \mathrm{C}-1 \mathrm{~min}$ & 35 \\
\hline \multirow{2}{*}{ ETEC } & lt & $95^{\circ} \mathrm{C}-1 \mathrm{~min}$ & $60^{\circ} \mathrm{C}-1 \mathrm{~min}$ & $72^{\circ} \mathrm{C}-2 \mathrm{~min}$ & 30 \\
\cline { 2 - 6 } & st & $95^{\circ} \mathrm{C}-1 \mathrm{~min}$ & $60^{\circ} \mathrm{C}-1 \mathrm{~min}$ & $72^{\circ} \mathrm{C}-1 \mathrm{~min}$ & 30 \\
\hline \multirow{2}{*}{ EIEC } & ipaH & $94^{\circ} \mathrm{C}-1.5 \mathrm{~min}$ & $60^{\circ} \mathrm{C}-90 \mathrm{sec}$ & $72^{\circ} \mathrm{C}-90 \mathrm{sec}$ & 35 \\
\hline DAEC & daaE & $94^{\circ} \mathrm{C}-1.5 \mathrm{~min}$ & $60^{\circ} \mathrm{C}-90 \mathrm{sec}$ & $72^{\circ} \mathrm{C}-90 \mathrm{sec}$ & 35 \\
\hline EAEC & aafII & $94^{\circ} \mathrm{C}-1.5 \mathrm{~min}$ & $60^{\circ} \mathrm{C}-90 \mathrm{sec}$ & $72^{\circ} \mathrm{C}-90 \mathrm{sec}$ & 35 \\
\hline
\end{tabular}

Fig.1 Detection of eaeA gene of enteropathogenic and enterohaemorrhagic E. coli in seafood samples

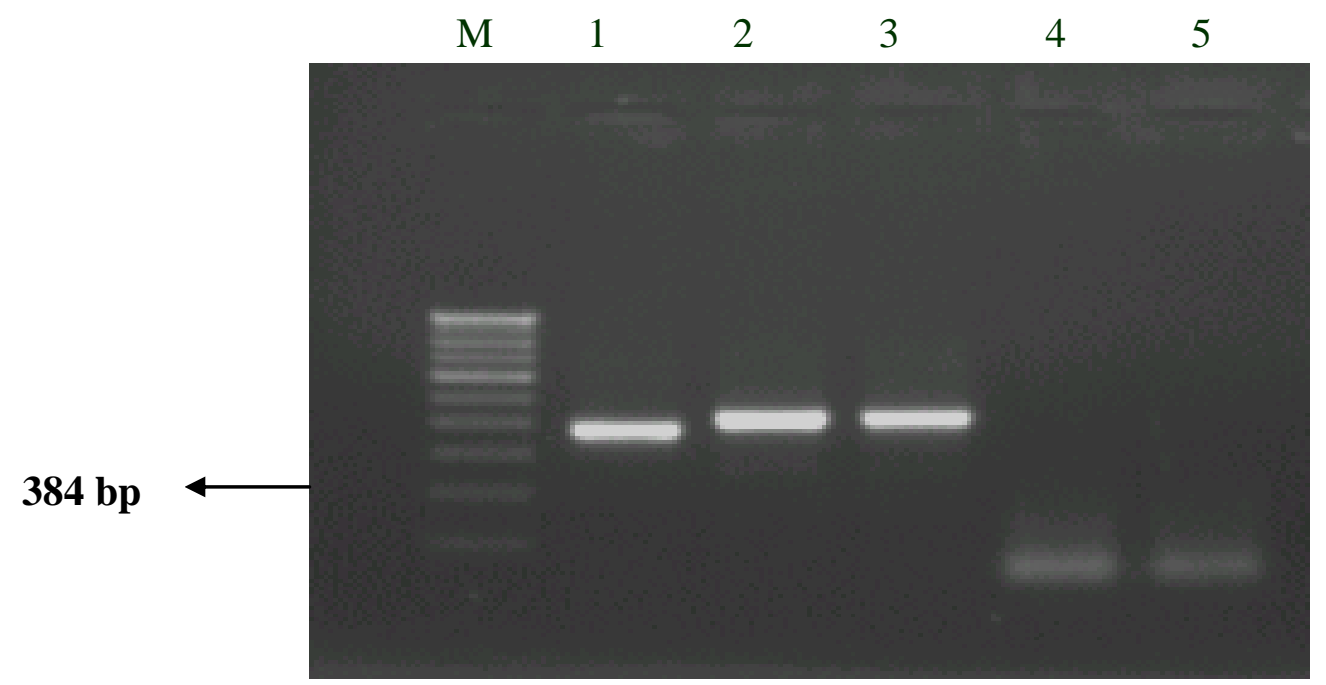

Lane M: 100 bp DNA ladder

Lane 1: Reference strain EDL 933 (E. coli O157:H7)

Lane 2: Squid sample positive for eaeA gene

Lane 3: Fish sample positive for $e a e A$ gene

Lane 4 -5: Negative control

Shellfish are known to harbour faecal coliforms since they filter large quantities of water. Being coastal and intertidal, it is to be expected that if there is faecal pollution in the coastal environments, the sanitary quality of water is bound to be affected and consequently the oysters. In an attempt to recover ETEC and EHEC from fish samples in retail markets of Cochin, Thampuran et al.,
(2005) observed that atypical E. coli with blood haemolysing property were present in fish and shellfish. The present study showed the absence of ETEC pathotype from aquatic environment and seafood samples. Pathogenic E. coli in environment samples off Velar estuary revealed that the organism was detected in fish, crustaceans and bivalves with percentage positivity being $30.1 \%, 29.7 \%$, 
and 51\%, respectively (Ramesh et al., 1991). Hatha et al., (1993) isolated 107 strains of pathogenic E. coli from water, sediment and fish off Bhavani River. The fish and shellfish from various cities of north India were screened for pathogenic E. coli by Singh and Kulashrestha (1994). Thampuran et al., (2005) reported that typical E. coli O157 or labile toxin- producing $E$. coli was absent in the fish and fishery environments of Cochin (India). Enterotoxigenic E. coli (ETEC) were identified as the etiologic agent in a large number of foodborne outbreaks at a sushi restaurant in Nevada. Poor food-handling practices and infected food handlers likely contributed to this outbreak (Jain et al., 2008). Dupray et al., (1999) detected stx genes in shellfish enrichments but no attempt was made to isolate STEC strains from positive samples. The results of this study suggest that PCR will be helpful in detecting samples possessing small numbers of pathogenic $E$. coli, which may be missed by conventional methods (Kumar et al., 2001). Dhanashree and Mallya (2008) showed a low incidence of STEC and high prevalence of eaeA positive $E$. coli other than STEC in stool and meat samples. This supports the findings of the present study with low prevalence of eaeA positive E. coli in seafood. Sehgal et al., (2008) observed enterohaemorrhagic E. coli isolates to be distributed among domestic and wild animals and the maximum number of isolates of E. coli $\mathrm{O} 157$ was detected in samples received from coastal belt areas.

In this study, 3 of 66 samples showed the presence of pathogenic E. coli. These 3 samples (two squid and one flat fish) were collected from a landing centre in Mangalore. These 3 seafood samples were positive for eaeA virulence gene of EHEC/EPEC and negative for other virulence genes of pathogenic E. coli. The prevalence of eaeApositive $E$. coli while being negative for other virulence genes of enterohaemorrhagic $E$. coli like stx and $h l y A$ as determined in this study, was $4.54 \%$ in seafood samples. This result suggests that the isolates obtained in this study may possibly be atypical EPEC. The presence of non- EPEC serotypes that carry $e a e A$ and lack $b f p A$ and Shiga toxin (stx) gene sequences have been found in acute diarrhea (Vieira et al., 2001). Brown and Hartland (2002) reported on the genotypic characteristics of $E$. coli strains of nonenteropathogenic E. coli (EPEC) serogroups that carry eaeA and lack the EPEC adherence factor and Shiga toxin genes. Reports from developed countries have shown that atypical EPEC strains (eaeA+, bfpA- and stx-) are more prevalent than typical EPEC strains (Paciorek, 2002; Trabulsi et al., 1996). However, eaeA positive E. coli requires further study with regard to their virulence and epidemiologic significance. Sewage contamination of fish harvesting areas may be the major reason for the presence of $E$. coli, but contamination can occur through the use of non- potable water or ice in the landing centers or fish markets (Kumar et al., 2005). The use of animal manures can result in the contamination by certain pathogenic types such as Shiga toxin-producing E. coli for which bovine reservoirs have been identified (Johannessen et al., 2005). Therefore, it is important that all stages of fish production, handling and processing are monitored for $E$. coli contamination.

\section{References}

Brown, and Hartland, E.L., 2002. Identification of a novel fimbrial gene cluster related to long polar fimbriae in locus of enterocyte effacement-negative strains of enterohemorrhagic Escherichia coli. Infect. Immun., 70: 6761-6769.

Dhanashree, B., and Mallya, P.S., 2008. Detection of Shiga-toxigenic Escherichia coli (STEC) in 
diarrhoeagenic stool and meat samples in Mangalore, India. Ind. J. Med. Res., 128: 271-277.

Dupray, E., Caprais, M.P., Derrien, A., Monfort, P., Convenant, A., Penot, J., Fach, P., Dilasser, F., Perelle, S., Grout, J., Federighi, M., Jugiau, F. and Rama, F., 1999. Flux bacteriens et qualité sanitaire des coquillages en baie de la Fresnaye. In Pollutions diffuses: $d u$ bassin versant au littoral, ed. M. Merceron, pp. 169-178.

Fagan, P.K., Hornitzky, M.A., Bettelhalim, K.A. and Djordjevic, S.P., 1999. Detection of Shiga- Like toxin (stxl and st $x 2), \quad$ intimin $(e a e A)$ and enterohaemorrhagic $E$. coli hemolysin (EHEC $h l y A$ ) genes in animal faeces by multiplex PCR. Appl. Environ. Microbiol., 65: 868- 872.

Feldhusen, F., 2000. The role of seafood in bacterial foodborne diseases. Microb. Infect., 2: 1651-1660

Feng, P., and Hartman, P.A., 1995. Flurogenic assays for immediate confirmation of Escherichia coli. Appl. Environ. Microbiol., 43: 1320-9.

Fischer, Helmut M.D., Konig, Paul M.D., Dierich, Manfred, P.M.D., Allerberger. and Franz, M.D., 2001. HemolyticUremic syndrome surveillance to monitor trends in infection with Escherichia coli $\mathrm{O} 157$ and non-O157 enterohemorrhagic E. coli in Austria. Pediatr. Infect. Dis. J., 20: 316-318.

Gordon, J., and Small, P.L.C., 1993. Acid resistance in enteric bacteria. Infect. Immun., 61: 364-367

Gunzburg, S.T., Tornieporth, N.G. and Riley, L.W., 1995. Identification of enteropathogenic Escherichia coli by PCR-based detection of the bundleforming pilus gene. J. Clin. Microbiol., 33: $1375-1377$

Hatha, A.M., Gomathinayagam, P. and Laxmanperumalswamy, P., 1993.
Incidence of multiple antibiotic resistant E. coli in Bhavani river. World $J$. Microbiol. Biotechnol., 9: 609- 610

Jimenez, L., Munir, J., Toranzos, G.G. and Hazen, 1989. Survival and activity of Salmonella typhimurium and Escherichia coli in tropical freshwater. J. Appl. Bacteriol., 67: 61- 69.

Johannessen, G.S., Bengtsson, G.B., Heier, B.T., Bredholt, S., Wasteson, Y. and Rorvik, L.M., 2005. Potential uptake of Escherichia coli 0157:H7 from organic manure into crisphead lettuce. Appl. Environ. Microbiol., 71: 2221-2225

Kaper, J.B., Nataro, J.P. and Mobley, H.L., 2004. Pathogenic Escherichia coli. Nat. Rev. Microbiol., 2: 123- 40

Karunasagar, I., Karunasagar, I., Parvathi, A. 2005. Microbial Safety of Fishery Products. Mangalore, India. Mangalore University of Agricultural Sciences.http://drs.nio.org/drs/bitstream /2264/79/1/Karunasagar_chap14.pdf, Accessed on 20 May 2007.

Kumar, H. S., Parvathi, A., Karunasagar, I. and Karunasagar, I., 2005. Prevalence and antibiotic resistance in Escherichia coli in tropical seafood. World $J$. Microbiol. Biotechnol., 21: 619-623.

Kumar, S. H., Otta, S. K., Karunasagar, I. and Karunasagar, I., 2001. Detection of Shiga-toxigenic Escherichia coli (STEC) in fresh seafood and meat marketed in Mangalore, India by PCR. Lett. Appl. Microbiol., 33: 334-338.

Lin, Z., Kurazono, H., Yamasaki, S. and Takeda, Y., 1993. Detection of various variant verotoxin genes in Escherichia coli by polymerase chain reaction. Microbiol. Immunol., 37: 543- 548.

Olsivik, O., and Strockbine, N.A., 1993. PCR detection of heat- stable, heat labile and Shiga-like toxin genes in Echerichia coli, pp. 271-276. In: Persing, D.H., Smith, T.F., Tenovar, F.C and White, T. J., (Eds). Diagnostic molecular 
microbiology: principles and applications. Mayo Foundation, Rochester, N.Y. pp. 271- 276

Paciorek, J., 2002. Virulence properties of Escherichia coli faecal strains isolated in Poland from healthy children and strains belonging to serogroups $\mathrm{O} 18, \mathrm{O} 26, \mathrm{O} 44$, $\mathrm{O} 126$ and $\mathrm{O} 127$ isolated from children with diarrhoea. J. Med. Microbiol., 51: 548- 556.

Paton, J.C., and Paton, A.W., 1998. Pathogenesis and diagnosis of Shiga toxin-producing Escherichia coli infections. Clin. Microbiol. Rev., 11: 450-79.

Pereira, M.A., Nunes, M.M., Nuernberg, L., Schulz, D. and Batista, C.R.V., 2006. Microbiological quality of oysters (crassostrea gigas) produced and commercialized in the coastal region of florianolis - Brazil. Braz. J. Microbiol., 37: 159-163.

Potasman, I., Paz, A. and Odeh, M., 2002. Infectious outbreaks associated with bivalve shellfish consumption: a worldwide perspective. Clin. Infect. Dis., 35: 921-928.

Ramesh, H., Kuboto, H., Hata, Y., Kastube, Y. and Shimonishi, Y., 1991. Molecular structure of the toxic domain of heat stable enterotoxin produced by a pathogenic strain of E. coli. J. Biol. Chem., 266: 5934-5941

Regine, H.S.F.V., Dalia, P. R., Norma, S.S. E., Grace, N.D. T. and Eliane, M.F. R., 1998. Colimetry of marine waters off Fortaleza (Ceara State, Brazil) and detection of enteropathogenic Escherichia coli strains. Int. Microbiol., 1: 221-22

Rhodes, M.W., and Kator, H., 1988. Survival of Escherichia coli and Salmonella spp. in estuarine environments. Appl. Environ. Microbiol., 54: 2902-2907

Schultsz, C., Pool, G.J., Vanketel, R., Dewever, B., Speelman, P. and Dankert, J., 1994. Detection of enterotoxigenic Escherichia coli in stool samples by using nonradioactively labeled oligonucleotide DNA probes and PCR.

J. Clin. Microbiol., 32: 2393-2397

Sehgal, R., Kumar, Y. and Kumar, S., 2008. Prevalence and geographical distribution of Escherichia coli $\mathrm{O} 157$ in India. Trans. R. Soc. Trop. Med. Hyg., 102: 380-383

Singh, B.L., and Kulsherestha, S.C., 1994. Incidence of $E$. coli in fishes and seafoods; isolation, serotyping, biotyping and enterotoxigenecity evaluation. J. Food Sci. Technol., 19: 94- 196

Singh, B.L., and Kulsherestha, S.C., 1994. Incidence of $E$. coli in fishes and seafoods; isolation, serotyping, biotyping and enterotoxigenecity evaluation. J. Food Sci. Technol., 19: 94- 196

Stephen, S., Indrani, R., Kotian, M., and RAO, K.M.A., 1975. Isolation of enteropathic $E$. coli from seafood and freshwater mussels. Ind. J. Microbiol., 15: 64-67.

Teophilo, G.N.D., Vieira, R.H. S.F., Rodrigues, D.P. and Menezes, F.G.R., 2002. Escherichia coli isolated from seafood: toxicity and plasmid profiles. Int. Microbiol., 5: 11-14.

Thampuran, N., Surendraraj, A. and Surendran, P.K., 2005. Prevalence and characterization of typical and atypical Escherichia coli from fish sold at retail in Cochin, India. J. Food Protect., 68: 2208-2211.

Trabulsi, L., Campos, L., Whittam, T., Gomes, T., Rodrigues, J. and Goncalves, A., 1996. Traditonal and non-traditional enteropathogenic Escherichia coli serogroups. Rev. Microbiol., 84: 585- 592

Varnam, A.H., and Evans, M.G., 1991. E. coli. In: Food borne pathogens: An illustrated text Wolfe Publishing Ltd., England. 101- 128 
Vidal, R., Vidal, m., Lagos, r., Levine, m. And Prado, v., 2004. Multiplex PCR for diagnosis of enteric infections associated with diarrheagenic Escherichia coli. J. Clin. Microbiol., 42: 1787-1789

Vieira, R.H.S.F., Rodrigues, D.P., Gocalves, F.A., Menezes, F. G.R., Aragao, J.S. and Sousa, O.V., 2001. Microbicidial effect of medicinal plant extracts (Psidium guajava Linn. and Carica papaya Linn.) upon bacteria isolated from fish muscle and known to induce diarrhea in children. Rev. Inst. Med. Trop. S. Paulo., 43: 145-148

YamasakI, S., Lin, Z., Shirai, H., Terai, A., Oku, Y., ITO, H., Ohmura, M., Karasawa, T., Tsukamoto, T., Kurazono, H. and Takeda, Y., 1996. Typing of verotoxins by DNA hybridization with poly and oligonucleotide probes, a beadenzyme- linked immunosorbent assay and polymerase chain reaction. Microbiol. Immunol, 40: 345- 352.

\section{How to cite this article:}

Koteswar, B., A. Devivaraprasad Reddy, G. Ravi and Indrani Karunasagar. 2017. Occurrence of Pathotypes of Escherichia coli in Aquatic Environment. Int.J.Curr.Microbiol.App.Sci. 6(9): 3266-3275. doi: https://doi.org/10.20546/ijcmas.2017.609.402 